\title{
Determining business value according to FCFE
}

\author{
Zuzana Rowland $^{1, *}$ and Tomas Stanek ${ }^{1}$ \\ ${ }^{1}$ Institute of Technology and Business, School of Expertness and Valuation, Okruzni 517/10, 37001 \\ Ceske Budejovice, Czech Republic
}

\begin{abstract}
The large number of joint stock companies causes that investors strive for better awareness and information in the stock area. The objective of the contribution is to apply the method of discounted FCFE in the valuation of a specific company and to determine the parameters for the model application in practice. The data for the analysis are obtained from the database of Kofola ČeskoSlovensko a.s. The data are taken from the published annual reports for the years 2018 and 2019. First, a financial plan for a period of stability was created. Subsequently, the discount value of the company was calculated using the FCFE model. Finally, the calculation of the company value in the continuation phase was calculated. To achieve the research goal, the individual FCFE need to be discounted by the value of equity using the CAMP model. In conclusion, it can be assumed that the discount rate will remain stable and the prediction of the growth rate will not change. If there are no fundamental changes in the company e.g. in terms of dividend payment, investment activities, or changes in the working capital, it can be assumed that the value of the company should be stabilized until 2021.
\end{abstract}

Keywords: stock companies, discounted FCFE, financial plan, discount rate, dividend policy

\section{Introduction}

The current period of economic welfare, financial staility, and availability of financial markets encourages new investments [1]. One of the many possibilities are equity funds. Many joint stock companies issue a large volume of stock. The large number of joint stock companies causes that investors strive for better awareness and information in this area so that their investments are proven and safe if possible [2]. Therefore, the question is how to find out the most accurate information about the fair value of a company. A clear and reliable method from the area of business valuation is only the FCFE (Free Cash Flow to Equity) model, that is, free cash flow for owners [3-4].

It shall be said in the introduction that this model is used especially in companies which do not achieve high monetary value only due to their high indebtedness. The FCFE model is based mainly on the DDM (dividend discount models).

In some cases, the company shall not be evaluated on the basis of actual dividends paid only. A more realistic view is offered by a model that deals with a potential dividend paid,

\footnotetext{
* Corresponding author: rowland@mail.vstecb.cz
} 
which includes retained earnings the company retains for the purposes of future investments. In the following chapters, it will thus be examined whether the company pays too high or too low dividends, how this could be measured, and subsequently, how much money can be paid to shareholders after the reinvestment activities are carried out.

The objective of the paper is to apply the method of discounted FCFE in the valuation of a specific company and to determine the parameters for the model application in practice.

\section{Literature review}

The valuation methods are currently a common method in everyday business activities. Companies, regardless of their size, are regularly valued in order to review their progress. Progress is an integral part of performing the future plans and determining the company's actual competitive position, as Patelis and Grose [6] say. A special approach to property valuation is in the case of the companies, whose assets are divided into a certain number of shares. Joint stock companies represent a unique group of companies that decide for the socalled "corner solution" in the case of their capital structure. Each company has a different motivation for setting all shares related to free cash flows and growth opportunities [7].

As already mentioned in the introduction, the criterion for assessing the value of a project using a method of discounted cash flow is FCFE. This was confirmed by Chu, Wang, and Feng [8]. In terms of addressing the modelling method, it can be said that economic modelling is not suitable for using FCFE; on the other hand, FCFE is the best method to explain the financial aspect [9].

The nature of long-term management and investment in the company's future leads to the distribution of funds to shareholders by means of repurchase of shares. The question to be asked is whether the repurchase of shares could be considered equity undervaluation. This is not only investment in the repurchase of shares but also a confirmation that regular payment of dividends to shareholders creates more funds for challenges the company receives [10]. Incorrect interpretation of capital budget may cause considerable problems in the redistribution of capital and structure of its components. The fact that there are at least ten methods to estimate the free cash flow and discount rate can be confusing and inaccurate in specific cases. When using these models, application risks may arise, without calculating the overall capital costs of the company. This problem leads to value-reducing investment decisions. FCFE or free cash flow to equity combined with the EVA model is the most efficient method of analysis [11].

Burns, McTiera, and Midnicka [12] argue that the effects of compensation and protection of shareholders in the policy of dividend payment, limited stock and dividend compensation are negative. If the motivation compensation is protected against dividends, the actual payment of dividends incresases. In countries with low investor protection, higher dividends are paid, in an effort to maintain the reputation of distrivution of excessive free cash flow. This reduced the dividends (since they increase the purchase), with regard to increased compensation of incentive stock.

Within this issue, several difficulties may appear. This is confirmed by Jackowicz, Meilcarz, and Wnuczak [13], who claim that the determination of the correct method of capital cash flow includes many doubts. These doubts may result in serious mistakes. The method of potential dividends leads to incorrect valuation of investments. The problems with free cash flow result from the mandatory payment of capital. However, if they repurchase the shares within five years, they show stagnant management [14].

The opinion of Jiménéz and Paucual [15] is very inspiring. They claim that the dividend yields are used for linking the stock market valuation to basic cash flows. Dividend yields thus must be stationary. Beschwitz [16] mentions the fact that the fied and fair value of a 
company may be affected e.g. by the sale of shares without the capital duty, as in the case of Germany after the introduction of the tax reform.

Naturally, all these situations are closely interlinked with the accounting sector. Various incentives within setting of shares, which are interlinked with free cash flows and growth opportunities, influence and affect the quality of accountings. Significantly different quality of accountings occurs in extreme situations of free cash flow compared to others. Fair capital strategy should not be generalized for all companies [17].

The state of differentiation of diversified companies is addressed by Nguyen, Cai, McCalgan [18], who believe that diversified companies retain much less cash that specialized companies. Companies adjust their cash flows to reach their target cash balance. Diversified companies show a higher free cash flow due to the same cash flows in the operation. Diversified companies save less money also due to lower debt and equity and the distribution of higher dividends.

Caban [19] emphasizes that the equity structure is affected by two factors: free cash flows and the so-called growth opportunities. The company shows higher costs compared to its competitors, if it has a high level of FCFE and low level of growth opportunities. The financial management usually does not value all assets at the same time, including the financial assets, which are not used for production. The value of equity, however, should be the same for boh methods of calculating FCF valuation [20].

Finally, it can be said that the company must be aware of its financial situation as well as its future plans and goals. In this respect, it is necessary to carry out regular valuation, which can take many forms.

The methodology for the FCFE model analyses the basic phenomena, theoretical and practical information leading to the best possible investigation of this issue and findings. Even in this FCFE model, there are clearly defined procedures, which will be addressed from the whole to their parts. The analysis of the creation of this model must comply with its system, which enables the separation of the significant and the insignificant, and identification of the properties of phenomena and processes. Specifically, in this issue, it is necessary to use the mathematical formulation of theoretical hypotheses which are subject to mathematical operations. This enables a precise formulation of phenomena and their mutual relations. It is necessary to follow the theoretical guidelines and carefully determine the examined company, which has a financial leverage for this model, since otherwise the model could not be applied. It is necessary to rely on a fixed discount rate, which is linked to the financial flow risk, to have sufficient information for all procedures. Companies which are tradable on capital market, pay dividends, o have relatively low financial leverage should be strictly avoided, as the FCFE model would not have informative value as e.g. dividend model. Finally, it is recommendable to use synthesis and to combine the findings from the aforementioned methods into a whole.

\section{Data and methods}

The data for the analysis were obtained from the database of Kofola ČeskoSlovensko a.s. [22]. The data are taken from the published annual reports for the years 2018 and 2019. The annual report is released after the end of accounting year in every calendar year, and it is a 180-page report containing the information provided by the management of the company, consolidated financial statement, and separate financial statement.

The data from the annual report will be used for the calculation of the company value using the discounted model FCFE. The table below show the individual items. The annual reports are from the years 2018 and 2019; it includes all products manufactured under the brand Kofola ČeskoSlovensko a.s. The data will be used for the calculation of FCFE (free cash flow for equity). This cash flow is riskier than the FCFF cash flow. 
Table 1. Values for calculation

\begin{tabular}{|l|r|r|r|r|}
\hline $\begin{array}{c}\text { Items for } \\
\text { calculating FCFE }\end{array}$ & $\begin{array}{c}\text { Data from 2018 } \\
\text { (thousand CZK) }\end{array}$ & $\begin{array}{c}\text { Data from 2019 } \\
\text { (thousand CZK) }\end{array}$ & $\begin{array}{c}\text { Data from 2020 } \\
\text { (thousand CZK) }\end{array}$ & $\begin{array}{c}\text { Data from 2021 } \\
\text { (thousand CZK) }\end{array}$ \\
\hline Net profit & $166,888,-$ & $156,921,-$ & $164,690,-$ & $171,653,-$ \\
\hline Investment & $143,430,-$ & $146,264,-$ & $149,306,-$ & $152,439,-$ \\
\hline $\begin{array}{l}\text { Change in working } \\
\text { capital }\end{array}$ & $92,021,-$ & $-259,-$ & $-278,-$ & $-287,-$ \\
\hline Repayment & $1,426,-$ & $1,425,-$ & $1423,-$ & $1422,-$ \\
\hline Depreciation & $159,181,-$ & $155,789,-$ & $153,722,-$ & $152,685,-$ \\
\hline $\begin{array}{l}\text { Payment of } \\
\text { preferred dividends }\end{array}$ & $68,186,-$ & $66,258,-$ & $67,603,-$ & $71,294,-$ \\
\hline
\end{tabular}

Source: Own processing according to Kofola ČeskoSlovensko a.s. [22].

From the annual reports of Kofola ČeskoSlovensko a.s. [22], there were selected data for the years 2018 and 2019 necessary for the calculation of business value using FCFE.

The calculation will be carried out using a mathematical method, that is, entering the relevant data in a numerical form in the formula. Subsequently, the calculation will be carried out and thus the required result (calculated business value) will be achieved.

The following formula explains in detail the calculation.

$$
\begin{gathered}
F C F E=\text { net profit }+ \text { depreciation }- \text { investments }- \text { change in working capital }- \\
\text { repayment }- \text { payment of preferred dividends }
\end{gathered}
$$

The data used for the calculation are presented in Table 1 above. In the calculation the data from all four years $(2018,2019,2020,2021)$ will be considered. The data for the years 2020 and 2021 were obtained from the financial survey of the company carried out by Komerční banka. First, a financial plan for a period of stability will be created (the years 2018 and 2019). Subsequently, the discount value of the company will be calculated using the FCFE model. Finally, the calculation of the company value in the continuation phase will be calculated.

This calculation enabled the determination of the value of the company. The calculation based on the data from one year would be distorting; therefore, the values of all four years will be averaged for greater accuracy of results. However, the objective was the calculation of the discounted value of the company using the FCFE model. Since in this method, only equity is considered, the discount rate equals the costs of equity. It thus eliminates any financial and operating risk. This indicates the current indebtedness of the company.

To estimate the cost of equity, the CAPM model can be used. It was originally used for securities tradable on the capital market. For its calculation, the formula given below is used.

The data for the individual variables are obtained from the financial survey conducted by $\mathrm{KB}$ in 2018 and 2019 [23]. The discount rate will be calculated using the formula:

$$
R_{e}=R_{f}+\beta_{i}^{*}\left[E\left(R_{m}\right)-R_{f}\right]
$$

A sum of risk-free rate and systematic risk of the i-th security multiplied by expected yield of market portfolio reduced by risk-free rate. The individual variables are $R_{e}=$ discount rate, $R_{f}=$ risk-free rate, $\beta_{i}=$ systematic risk of the i-th security, and $E\left(R_{m}\right)=$ expected yield of market portfolio.

This formula will be calculated for discounting FCFE and subsequently for the results in individual years. The data for the calculation were taken from Damodaran [21] and the financial survey of KB [23]. After the basic FCFE model for the valuation of the company is calculated, the discounted FCFE is calculated. The value of the FCFE in the first phase 
will be obtained by the sum of discounted FCFE for individual years in the period of stability. Furthermore, the terminal value will be calculated using the following formula: $P H=F C F E_{t} /\left(r_{e^{-}} g\right)$. Another step is entering the variables in the formula for calculating the value of the company in the continuing phase: $P H /\left(1+R_{e}\right)^{T}$. After that, the value of the company from the first phase will be added up with the value of the company in the continuing phase. This way it will be possible to obtain the resulting value of the company.

In this case, the calculation of the following years includes the prediction of the growth rate of $1.4 \%$ up to the year 2023 . The data for all years were provided by KB on the basis of the financial survey of Kofola ČeskoSlovensko [23]. The results will be then presented in a summary table with a necessary explanation. Subsequently, the value of the company will be assessed to gether with the comparison of year-on-year growth or decrease of value and final conclusion.

\section{Results}

The data analysis will be performed in accordance with the aforementioned methodology. The data from Table 1 will be used for the calculation using the following formula for the calculation of FCFE already mentioned in the methodology:

The result for 2018 is calculated as follows:

$$
F C F E_{2018}=166,888+159,181-143,430-92,021-1,426-68,186=21,006
$$

The result for 2019 is calculated as follows:

$$
F C F E_{2019}=156,921+155,789-146,264-(-278)-1,425-66,258=99,041
$$

The result for 2020 is calculated as follows:

$$
F C F E_{2020}=164,690+153,722-149,306-(-278)-1,423-67,603=100,358
$$

The result for 2021 is calculated as follows:

$$
F C F E_{2021}=171,653+152,685-152,439-(-287)-1,422-71,294=99,467
$$

To achieve the set goal, it is necessary to discount the value of the FCFE calculated of the individual years. Discounting will be based on the calculated value of $R_{e}$, using the following formula (2).

Following the calculation of the FCFE value and $R_{e}$, the discounted FCFE can be calculated using this formula:

$$
\text { Equity value }=F C F E_{t} /\left(r_{e}-g\right)
$$

Below, you can see the calculation of $R e$. For the year $2018, R_{e}$ will be calculated as follows:

$$
R_{e(2018)}=7.12+0.79 *(1.4-7.12)=2.6 \%
$$

For the year 2019, $R_{e}$ will be calculated as follows:

$$
R_{e(2019)}=7.12+0.79 *(2.1-7.12)=3.1542 \%
$$

For the year 2020, $R_{e}$ will be calculated as follows:

$$
R_{e(2020)}=7.12+0.79 *(2.1-7.12)=3.1542 \%
$$

For the year 2021, $R_{e}$ will be calculated as follows:

$$
R_{e(2021)}=7.12+0.79 *(2.1-7.12)=3.1542 \%
$$


For discounting, the values of FCFE and $R_{e}$ must be known. As the values were calculated within the previous steps, the discounts can be calculated:

Table 2. Calculation of discount

\begin{tabular}{|l|c|c|c|c|}
\hline & $\mathbf{2 0 1 8}$ & $\mathbf{2 0 1 9}$ & $\mathbf{2 0 2 0}$ & $\mathbf{2 0 2 1}$ \\
\hline FCFE & 21,006 & 99,041 & 100,358 & 99,467 \\
\hline Discount rate & $2.6 \%$ & $3.1542 \%$ & $3.1542 \%$ & $3.1542 \%$ \\
\hline Discounted FCFE & 20,474 & 93,077 & 91,431 & 87,848 \\
\hline Overall value & \multicolumn{4}{|c|}{292,830} \\
\hline
\end{tabular}

Source: Own processing.

The terminal value (TV) calculated as:

$$
F C F E_{2021} /\left(r_{e}-g\right)=87,848 /(3.1542-1.4)=50,079
$$

The value of the company in the continuing phase is calculated as:

$$
P H /\left(1+R_{e}\right)^{T}=50,079 /(1+0.031542)^{3}=45,624
$$

The resulting value of the company for the year $2021=292,830+45,624=338,454$ thousand CZK.

\section{Discussion}

As already mentioned in the previous paragraphs, the object of the study was the company Kofola ČeskoSlovensko a.s. The objective of the paper was to determine the value of the company using the model of discounted FCFE and to determine the parameters for the application of this model in practice. The initial values for the calculation for the years 2018, 2019, 2020, and 2021 are presented in Table 1 . The values in the table show a considerable change in the working capital of the company between 2018 and 2019, which affected the free cash flow for shareholders. Using a simple mathematical operation and entering the relevant values to the formula for calculating FCFE for individual years (the sum of net profit and depreciation reduced by costs of investments, change in working capital, repayment, and payment of dividends). To achieve the research goal, the individual FCFE need to be discounted by the value of equity using the CAMP model. Using the formula for calculating discount rate, where the risk-free rate $\left(R_{f}\right)$ and beta $\left(\beta_{i}\right)$ multiplied by the risk premium $\left(E\left(R_{m}\right)-R_{f}\right)$, this model enabled to determine the values presented in Table 2, which show that the discount rate increased by $0.5542 \%$ between 2018 and 2019 . This indicates that the value of discounted FCFE for the years 2019, 2020, and 2021 reduced and affected the value of the sum of the discounted FCFE in the period of stability. In the following step, the constant growth model and the growth rate were used to determine the terminal value of the company, which was necessary to calculate the value of the company in the continuing phase. The resulting value of Kofola ČeskoSlovensko a.s. for the year 2021 was determined on the basis of the sum of the discounted FCFE for the individual years and the value of the company in the continuing phase at CZK 338,454.

The FCFE model is applicable in the analysis of a company in practice provided that it is a company with a stable financing structure, so that given values can be reliably determined. There can be doubts whether to use the dividend discount models or FCFE. The decision is based on available information and data on the company [24]. FCFE has a better informative value and is applicable e.g. for the companies that cannot be traded on the capital market. These can be companies where there is a big difference between the dividends and FCFE, or public limited companies that do not pay dividends. The FCFE model can be used even in the situation where there is a significant number of majority shareholders who are allocated a large share of cash flows. These shareholders will most 
likely what that the cash flows are invested in profitable projects; for this reason, the dividends paid will be lower. The FCFE model can be used even in the case of low profit or loss [25].

\section{Conclusion}

The objective of the paper was to determine the value of a selected company using the model of discounted free cash flow to equity (FCFE) and to determine the parameters for its application in practice.

First, it was necessary to gather data from annual reports of the company Kofola ČeskoSlovensko a.s. and from publicly available financial surveys described in the methodology part of the paper. After obtaining all the necessary information, a basic formula for calculating FCFE and the value of equity was used to determine the value of discounted FCFE for all considered years (2018-2021). In another step, the formula for the calculation of the terminal value was used to determine the overall value of the company, which is estimated to CZK 338,454 for the year 2021. All the collected data are described, summarize, and presented in the Results of the paper. The performed analysis enabled the determination of the individual parameters that could be used by companies and valuers in practice. The basic parameters necessary for the application of the FCFE model are the net profit, depreciations, repayments, payment of dividends, and the degree of changes in the working capital. After obtaining the result on the basis of the formula used, the value of the company is significantly influenced by the discount rate and the expected growth rate.

The research has shown that to determine the value of a business, it is necessary to use a suitable model of analysis of free cash flows with regard to the situation of the company or the information available. The contribution of the work could be the specification of all parameters that can affect the behaviour of shareholders and managers when using the FCFE model in practice. Moreover, it can also help potential investors in decision making. A positive result of the FCFE model can be a signal for a company that decides to start its dividend policy or is going to invest the free cash flows in alternative projects where they can be valued.

In the future, it would be interesting to see how the global crisis caused by COVID 19 will affect the shares of the company and what influence their change will have on the value of the whole company.

In conclusion, it can be assumed that the discount rate will remain stable and the prediction of the growth rate will not change. If there are no fundamental changes in the company e.g. in terms of dividend payment, investment activities, or changes in the working capital, it can be assumed that the value of the company should be stabilized until 2021. The objective of the paper was thus achieved.

\section{References}

1. K. Valaskova, T. Kliestik, L. Svabova, P. Adamko, Financial risk measurement and prediction modelling for sustainable development of business entities using regression analysis. Sustainability, 10(7) (2018)

2. K. Valaskova, T. Kliestik, M. Kovacova, Management of financial risks in Slovak enterprises using regression analysis. Oeconomia Copernicana, 9(1), 105-121 (2018)

3. M. Vochozka, J. Horak, T. Krulicky, Innovations in management forecast: Time development of stock prices with neural networks. Marketing and Management of Innovations, 2020(2), 324-339 (2020) 
4. B. Groda, J. Vrbka, Prediction of stock price developments using the Box-Jenkins method. SHS Web of Conferences - Innovative Economic Symposium 2017: Strategic Partnership in International Trade (2017)

5. J. Vrbka, Z. Rowland, Stock price development forecasting using neural networks. SHS Web of Conferences - Innovative Economic Symposium 2017: Strategic Partnership in International Trade (2017)

6. G. Patelis N., CH. Grose, Employing valuation tools for public and private companies. The food sector in Greece. Procedia Economics and Finance, 33, 491-505 (2015)

7. B. Ayash, The origin, ownership and use of cash flows in leveraged buyouts. Quarterly Review of Economics and Finance, 77, 286-295 (2019)

8. X.L. Chu, S.G. Wang, K. Feng, Evaluating demand guarantee for PPP projects by realoption pricing. ICCREM: Prefabricated buildings, Industrialized Construction, and Public-Private Partnership, 155-162 (2017)

9. M. Lotti, G. Bonazzi, Profitability and financial sustainability analysis in Italian aquaculture firms by application of economic and financial margins. American Journal of Agricultural and Biological Science, 10, 18-34 (2015)

10. Y.N. Bhagwat, M. DeBruine, Do firms shave capital expenditures when repurchasing shares? Academy of Accounting and Financial Studies Journal, 22(6), (2018)

11. P. Mielcarz, F. Mlinaric, The superiority of FCFF over EVA and FCFE in capital budgeting. Economic Research-Ekonomska Istra, 27, 559-572 (2014)

12. N. Burns, B. McTier, K. Minnick, Equity-incentive compensation and payout policy in Europe. Journal of Corporate Finance, 30, 85-97 (2015)

13. K. Jackowicz, P. Mielcarz, P. Wnuczak, Fair value, equity cash flow and project finance valuation: ambiguities and a solution. Managerial Finance, 43, 914-927 (2017)

14. W. Bessler, W. Drobetz, M. Seim, Equity issues and stock repurchases of initial public offerings. European Financial Management, 22, 31-62 (2016)

15. L.G. Jiménez, L.B. Pascual, Enterprise valuation with track-record ratios and rates of change. European Journal of Finance, 16, 57-78 (2010)

16. B. von Beschwitz, Cash windfalls and acquisitions. Journal of Financial Economics, 128, 287-319 (2018)

17. D. Cabán, R. College, Managerial motivation behind an all-equity structure: The role of free cash flows and growth opportunities on accounting quality. Academy of Accounting and Financial Studies Journal, 24(1), (2020)

18. T. Nguyen, C. Cai, P.Mc. Colgan, How firms manage their cash flows: An examination of diversification's effect. Review of Quantitative finance and accounting 48, 701-724 (2017)

19. D. Caban, The motivational heterogeneity of an all-equity capital structure. Review of Accounting and Finance, 17, 215-237 (2018)

20. P.D. Easton, G.A. Sommers, Two different ways of treating corporate cash in FCF valuations - and the importance of getting the cost of capital right. Journal of Applied Corporate Finance, 29, 71-79 (2017)

21. Aswath Damodaran. Damodaran [online], Available
$\mathrm{http} / /$ people.stern.nyu.edu/adamodar/New Home Page/home.html (2020)

22. Kofola ČeskoSlovensko a.s. $\check{C} R$ : Ministry of Justice of the Czech Republic [online], Available at: https://or.justice.cz/ias/ui/vypis-sl-firma?subjektId=715045 (2018) 
23. Ekonomický a strategický výzkum [Economic and strategic research]. ČR: Komerční banka [online], Available at: https://www.investicniweb.cz/Files/kofola-cs-doporucenikb-cervenec-2019/ (2019)

24. S. Haskova, P. Suler, V. Machova, T. Krulicky, Determining the price of the business share of a business in a group. Ad Alta: Journal of Interdisciplinary Research, 9(2), 6070 (2019)

25. M. Vochozka, V. Stehel, Z. Rowland, Determining development of business value over time with the identification of factors. Ad Alta: Journal of Interdisciplinary Research, 9(2), 358-363 (2019) 